\title{
Growth rates of microalgae encapsulated in calcium alginate as a possible indicator of the trophic state of aquatic ecosystems
}

\author{
Gabriel A. Pinilla ${ }^{1, *}$ (iD, Luis Carlos Montenegro ${ }^{1}$ iD, Luz Marina Melgarejo ${ }^{1}$ iD), Nicolás \\ Molano-González² (D), Alfonso Pineda ${ }^{3}$ (D), Ibeth Paola Delgadillo ${ }^{4}$ (D) and Mario Andrés \\ Forero $^{1}$ iD \\ ${ }^{1}$ Department of Biology, Universidad Nacional de Colombia, Bogotá, Colombia. \\ 2 School of Medicine and Health Sciences, Universidad del Rosario, Bogotá, Colombia. \\ 3 Research Center on Limnology, Ichthyology and Aquaculture, Universidade Estadual de Maringá, Maringá, \\ Brasil. \\ ${ }^{4}$ Faculty of Science and Technology, Universidad Pedagógica Nacional, Bogotá, Colombia. \\ * Corresponding author: gapinillaa@unal.edu.co
}

Received: 26/09/19

Accepted: 28/09/20

\begin{abstract}
Growth rates of microalgae encapsulated in calcium alginate as a possible indicator of the trophic state of aquatic ecosystems

There are many applications for encapsulated algae but the use as an indicator of the trophic state of aquatic environments has not been explored in-depth. In this paper, the effects of different nutrient concentrations in two encapsulated algae, Scenedesmus obtusus, and Parachlorella kessleri, were analyzed both in the laboratory (batch systems) and in field experiments; the latter were carried out in four wetlands in the city of Bogotá. Linear models with heterogeneous variance (LMHV) were used to assess differences in the algal growth rates under different nutrient concentrations, and multivariate general linear models (MGLM) were used to relate the influence of abiotic factors under field conditions. The laboratory results showed an increase in growth rates with higher nutrient concentrations, while the field results were less clear, but differences were observed in physical variables between the wetlands and the growth rates over time. The combined analysis revealed variability in the growth rates under field conditions, making it difficult to relate each wetland with a respective nutrient concentration. These results are preliminary, and more research is needed, but they suggest that encapsulated algae growth rates could be used to evaluate the trophic status of aquatic environments.
\end{abstract}

Key words: alginate applications, Colombian Andes, Parachlorella kessleri, Scenedesmus obtusus, wetlands, water quality

\section{RESUMEN}

Tasas de crecimiento de microalgas encapsuladas en alginato de calcio como posible indicador del estado trófico de ecosistemas acuáticos

Las algas encapsuladas se han empleado de muchas formas diferentes, pero uno de los usos menos explorados es su papel como indicadoras del estado trófico en ecosistemas acuáticos. En este artículo, se analizaron los efectos de diferentes concentraciones de nutrientes en dos algas encapsuladas, Scenedesmus obtusus y Parachlorella kessleri, tanto en laboratorio (en sistemas "batch"), como en experimentos de campo en cuatro humedales de la ciudad de Bogotá. Se utilizaron modelos lineales con varianza heterogénea (MLVH) para evaluar las diferencias en las tasas de crecimiento de las algas bajo diferentes concentraciones de nutrientes, y modelos lineales multivariados generales (MLMG) para relacionar la influencia de los factores abióticos en condiciones de campo. Los resultados de laboratorio mostraron un aumento en las tasas de crecimiento con mayores concentraciones de nutrientes, mientras que los resultados de campo fueron menos claros, pero se observaron diferencias en las variables fisicas entre los humedales y en las tasas de crecimiento de las algas a lo largo del tiempo. El análisis combinado reveló una gran variabilidad de las tasas de crecimiento en los experimentos de campo, lo que dificulta asociar cada humedal a una concentración de nutrientes determinada. Estos resultados son preliminares y se requiere más 
investigación, pero sugieren que las tasas de crecimiento de algas encapsuladas podrían usarse para evaluar el estado trófico de los ambientes acuáticos.

Palabras clave: aplicaciones del alginato, Andes colombianos, Parachlorella kessleri, Scenedesmus obtusus, humedales, calidad del agua

\section{INTRODUCTION}

Freshwater ecosystems are negatively affected by increases in nutrient concentrations (eutrophication) resulting from human activities. A high eutrophication degree alters all levels of food webs (Bouraï et al., 2020), affecting human well-being and functions of freshwater ecosystems (Gunkel et al., 2015). In these environments, the plankton alga community plays an important role as a primary producer and is especially sensitive to changes in nutrient concentrations. Increased availability of nutrients influences the phytoplankton community structure because it promotes the growth of some species but inhibits others (Tilman et al., 1982; Zhu et al., 2010), which makes it possible to associate the growth of some phytoplankton species with certain trophic states (Reynolds, 2006; Bellinger \& Sigee, 2010). In field studies, it is challenging to determine the true effect of trophic status on species distribution because isolating the incidence of other ecological processes (e.g. competition, dispersion) that modify the species distribution patterns is difficult. To solve this problem microalgae immobilized in calcium alginate spheres (beads) have been used, which allow for the biomonitoring of the environmental status (Védrine et al., 2003; Luan et al., 2006; De-Bashan et al., 2008; Corrêa et al., 2009; Ruiz-Marin et al., 2010; Eroglu et al., 2015; Sukačová \& Červený, 2017; Valdez et al., 2018). However, very few studies using the alga immobilization technique for monitoring the trophic status in wetlands have been published (Twist et al., 1998; Pineda et al., 2017).

In this study, the effect of different nutrient concentrations on the growth of encapsulated algae in the laboratory and wetlands was assessed, isolating the effects of other factors and processes. The wetlands studied were four lentic environments of ecological and environmental importance for the city of Bogotá. Parachlorella kessleri
(Krienitz et al., 2004) and Scenedesmus (ovalternus syn.) obtusus (Meyen, 1829) were used; $P$. kessleri is sensitive to nutrient deficiencies and is usually present in well-mixed shallow eutrophic lentic environments (Reynolds et al., 2002; Reynolds, 2006); Scenedesmus genus is associated with eutrophic to hyper-eutrophic shallow lakes and rivers (Bellinger \& Sigee, 2010). We hypothesized that the algal species with the greatest capacity to absorb nutrients (P. kessleri) (Li et al., 2013) will exhibit the highest growth rate as the trophic state of water increases.

\section{METHODOLOGY}

\section{Algae culture conditions}

Scenedesmus obtusus (formerly Scenedesmus ovalternus, strain LAUN-001) and Parachlorella kessleri (strain LAUN-002) were provided by Algae Culture Laboratory (LAUN-Laboratorio de Algas, Departamento de Biología, Universidad Nacional de Colombia). Basic Bold Medium (BBM) was used at $22{ }^{\circ} \mathrm{C}$, with an aeration system, continuous stirring with ambient air, and a 16:8 h photoperiod (Forero-Cujiño et al., 2016; Delgadillo et al., 2017). This system was placed under cool, white fluorescent lamps (39 W, 1400 lux, radiation intensity $60 \mu \mathrm{E} \mathrm{m} \mathrm{m}^{2} \mathrm{~s}^{-1}$ ). For the tests, a batch-type culture system was established in $500 \mathrm{~mL}$ bottles containing a total culture volume of $250 \mathrm{~mL}$ for 10 days for each alga culture.

\section{Immobilization of algae in calcium alginate beads}

Algae in calcium alginate beads were immobilized following the methodology described by Forero-Cujiño et al. (2016). Each algal species was maintained separately at a proportion of $1: 1$ (alga: sodium alginate $4 \%$ in BBM). The cell 
concentration was determined using Neubauer chambers (Wetzel \& Likens, 2000). This proportion was named "algal preparation". Immediately, a solution of $0.66 \mathrm{~g}$ of calcium chloride $\left(\mathrm{CaCl}_{2} \cdot 2 \mathrm{H}_{2} \mathrm{O}\right)$ in $200 \mathrm{~mL}$ of distilled water was made and placed on an ice bed for preparing the alginate beads. $1 \mathrm{~mL}$ of algal preparation was aspirated with a syringe and drops were plunged into the calcium chloride solution to achieve $25 \pm$ 5 beads per $\mathrm{mL}$ of preparation. The volume of each bead was $0.04 \pm 0.01 \mathrm{~mL}$. The beads were kept in $2 \%$ calcium chloride and stored in the dark at $4{ }^{\circ} \mathrm{C}$ in a refrigerator $12 \mathrm{~h}$ to permit stabilization and hardening.

\section{Laboratory tests}

Encapsulated algae were subjected to the simulated trophic state values described by Vollenweider \& Kerekes (1980): oligotrophic state (Phosphate $0.01 \mathrm{mg} / \mathrm{L}$, Nitrate $1 \mathrm{mg} / \mathrm{L}$, Nitrite $0.5 \mathrm{mg} / \mathrm{L}$ ); Mesotrophic state (Phosphate $0.03 \mathrm{mg} / \mathrm{L}$, Nitrate $5 \mathrm{mg} / \mathrm{L}$, Nitrite $5 \mathrm{mg} / \mathrm{L}$ ); and Eutrophic state (Phosphate $0.1 \mathrm{mg} / \mathrm{L}$, Nitrate $50 \mathrm{mg} / \mathrm{L}$, Nitrite $15 \mathrm{mg} / \mathrm{L}$ ). The highest values of the trophic categories were used because the wetlands are in an urban context that provides them with large amounts of nutrients (Guillot \& Pinilla, 2017). We prepared three replicates of each treatment and three bottles of each replicate. The experi- ment unit was each bottle with $250 \mathrm{~mL}$ of medium simulating each trophic state, containing 250 beads per bottle. The laboratory tests were implemented in 10-day runs under the same algae culture conditions described above.

\section{Field trials}

The experiments were conducted in the dry (February - March) and rainy (April - June) periods of 2013. Four aquatic lentic ecosystems (henceforth called wetlands) were selected with different trophic states (Rodríguez \& Pinilla, 2017) in the Bogotá River basin $(2560$ - 2900 m a.s.l., on the Savannah of Bogotá, Eastern Cordillera of the Andes): San Rafael (oligotrophic state, $4^{\circ} 42^{\prime}$ 10.6" N, 73 59' 26.4" W); Santa María (mesotrophic state, $4^{\circ} 41^{\prime} 40.3^{\prime \prime} \mathrm{N}, 74^{\circ} 05^{\prime} 34.0^{\prime \prime} \mathrm{W}$ ); Juan Amarillo (hypertrophic state, $4^{\circ} 44^{\prime} 13.1^{\prime \prime} \mathrm{N}$, $74^{\circ} 06^{\prime} 47.5^{\prime \prime} \mathrm{W}$ ); and La Conejera (eutrophic state, $4^{\circ} 45^{\prime} 42.8^{\prime \prime} \mathrm{N}, 74^{\circ} 06^{\prime} 13.7^{\prime \prime} \mathrm{W}$ ) (Fig. 1). The latter was added in the rainy period to increase the environmental variability in our assays.

For each alga species, 200 beads were arranged in nylon bags (mesh size $\sim 0.7 \mathrm{~mm}$ ), named "bags with free beads". The experiment unit was each bag. Three bags were prepared for each species in each wetland. Controls were prepared with the same number of beads, which were placed in transparent plastic re-sealable
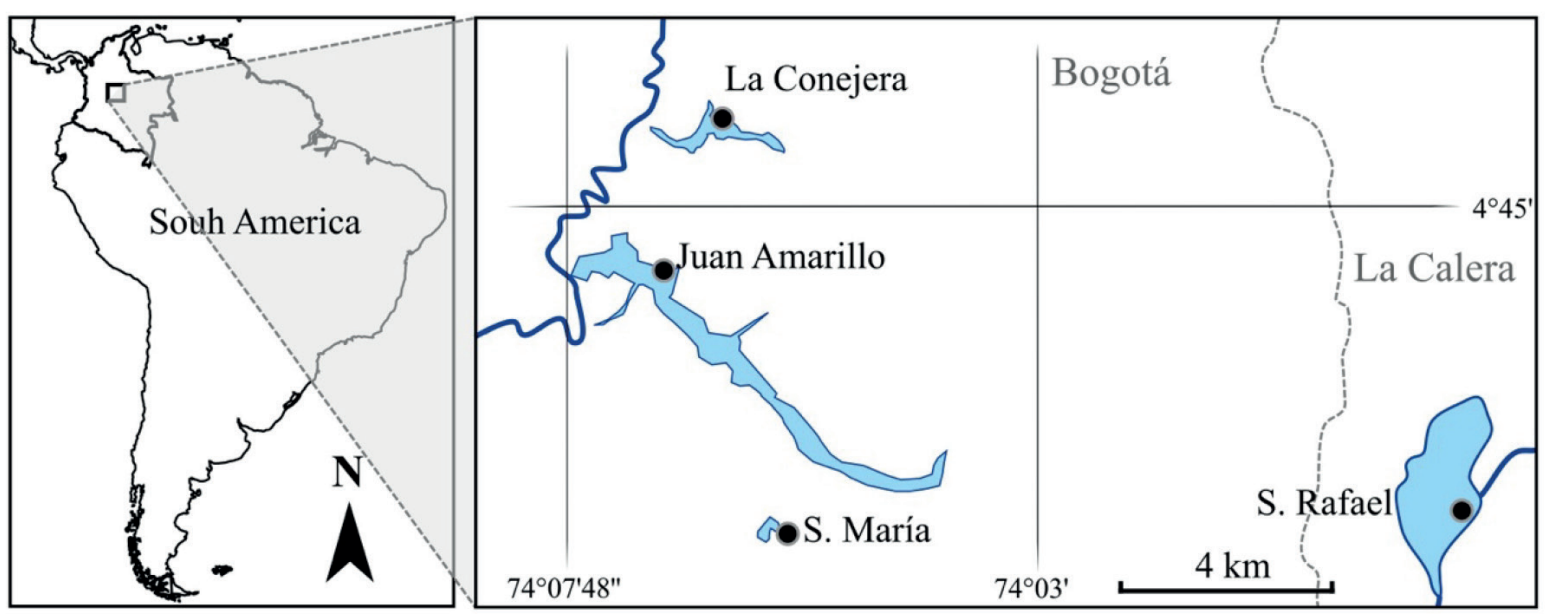

Figure 1. Location map of the wetlands studied in the city of Bogotá, Colombia. Mapa de ubicación de los humedales estudiados en la ciudad de Bogotá, Colombia. 
zipper storage bags containing culture medium (BBM). The re-sealable bags were placed into nylon bags (see details in Pineda et al., 2017). A polyvinyl chloride (PVC) frame was built for each species, into which three bags with free beads and three controls were placed (see schema in Pineda et al., 2017). The bags were placed at a depth of $10 \mathrm{~cm}$ and laid flat on a horizontal plane to make sure that they were exposed to the same amount of light. The percentage of light reduction by the nylon, measured in the laboratory, was around $12 \%$. To determining the light reduction by the nylon bag, a $60 \mathrm{~W}$ light bulb was covered with the nylon, and a Li-Cor portable meter and an LI-93 spherical quantum sensor (LI-COR, Nebraska, USA) were used to measure the light with and without the nylon bag. The difference between the two measurements was considered the reduction of light by the nylon bags. The controls allowed for the determination of whether the available light and temperature in the water ecosystems affected the growth of algae under conditions of optimum nutrient availability. For ten days, the PVC devices remained at each wetland in the littoral zone, anchored between one and two meters from the shore, and two meters away from each other. During each season and in each wetland, the following environmental variables were measured for ten days (throughout the trial duration): photosynthetically active radiation (subsurface and $10 \mathrm{~cm}$ depth PAR, $\mu \mathrm{mol} \mathrm{m} \mathrm{m}^{-2} \mathrm{~s}^{-1}$, measured with an LI-COR portable meter and an LI-193 spherical quantum sensor); electric conductivity $(\mu \mathrm{S} / \mathrm{cm})$, dissolved solids (DS mg/L), pH (units), dissolved oxygen (DO $\mathrm{mg} / \mathrm{L})$, percentage of oxygen saturation $(\%)$, temperature $\left({ }^{\circ} \mathrm{C}\right)$, and redox potential $(\mathrm{mV})$ with a HACH-HQd multi-parameter meter (Hach Company, Colorado, USA). Additionally, on the first, fifth, and tenth days of the experiments, the concentrations of ammonium $\left(\mathrm{NH}_{4}+\mathrm{mg} / \mathrm{L}\right)$, total nitrogen ( $\mathrm{TN} \mathrm{mg} / \mathrm{L}$ ), total phosphorus (TP $\mathrm{mg} / \mathrm{L}$ ), and chemical oxygen demand (COD, $\mathrm{mg} / \mathrm{L}$ ) were determined, for which samples were sent to a certified laboratory. For all procedures, the methodologies of Rice et al. (2012) were followed. The water light transmittance (TrL) was calculated using PAR measurements according to Kirk (2011).

\section{Algae growth rates}

Both in the laboratory and field experiments, the data were recorded daily with five beads from each experiment unit. The beads were dissolved in $1 \mathrm{~mL}$ of $4 \%$ sodium bicarbonate. To ensure a complete dilution, this solution was stored in the dark at $4{ }^{\circ} \mathrm{C}$ in a refrigerator for 24 hours. Subsequently, cell counts were carried out in Neubauer chambers. With these cell numbers, the growth rate $(\mu)$ of each species in each trial was determined as:

$$
\mu=\frac{\operatorname{Ln} N_{t 1}-\operatorname{Ln} N_{t 0}}{t_{1}-t_{0}}
$$

where, $N_{t 1}$ is the final cell number $\left(t_{1}\right.$, the last day of the experiments), and $N_{t 0}$ is the initial cell number $\left(t_{0}\right.$, the beginning day of the experiments) (Andersen, 2005).

\section{Statistical analysis}

Linear models with heterogeneous variance (LMHV) (described by Gałecki \& Burzykowski, 2013) were used to assess the differences in growth rates between $S$. obtusus and P. kessleri considering trophic conditions over time under the laboratory tests, and considering the wetlands and seasons under the field trials. The general approach was to fit an LMHV where $N$ in the $t_{i}$ time $\left(N_{t 1}\right)$ was modeled for time, alga species, and trophic condition in the laboratory, and for time, wetland, and season in the field trials. The heterogeneity variance was modeled as a power function of the mean population size at a given time to address the increased variance of the alga population size measurements throughout the study. Thus, the growth rates were estimated as the slope coefficient of time versus the number of cells for each combination of alga species and trophic condition for the laboratory experiment, and wetland and season in the field trials. Under the assumption of linearity, the slope corresponds to the same definition given above for $\mu$. The linear assumption in this study was chosen taking into account that the time-lapse of observation for each trial was not enough to capture the complete nonlinear sigmoid growth curve. 

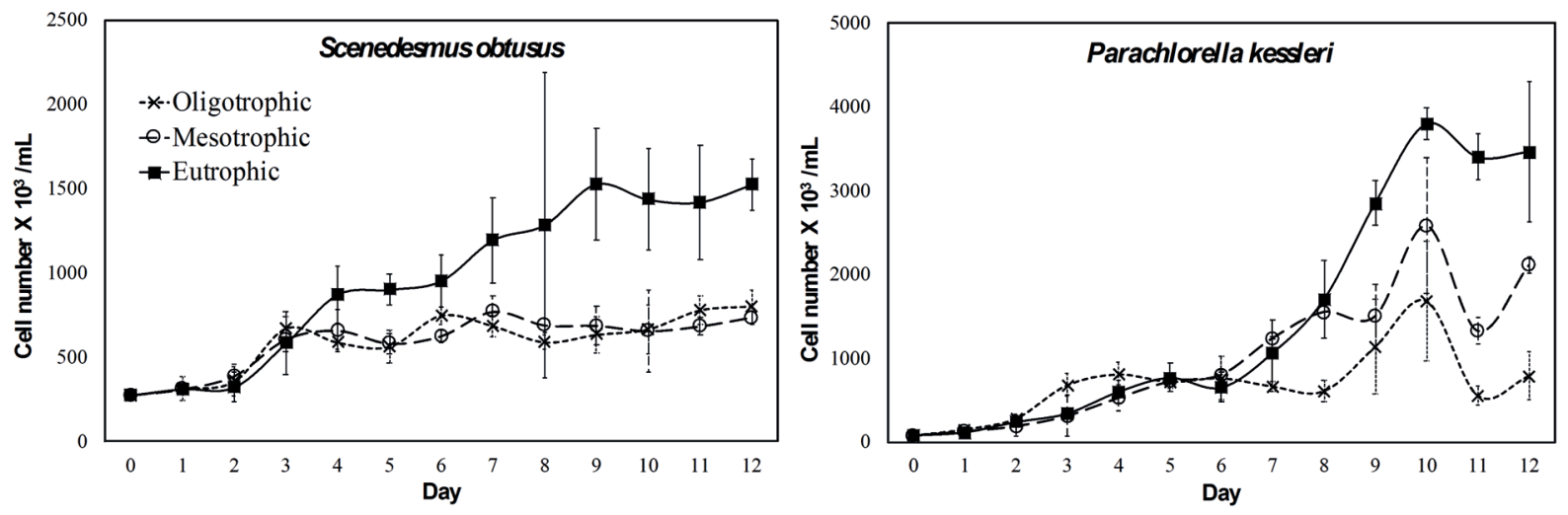

Figure 2. Growth curves of algae cultured in simulated trophic media. A. Scenedesmus obtusus. B. Parachlorella kessleri. Standard deviations of cell numbers are shown. Curvas de crecimiento de las algas cultivadas en medios tróficos simulados. A. Scenedesmus obtusus. B. Parachlorella kessleri. Se muestran las desviaciones estándar del número de células.

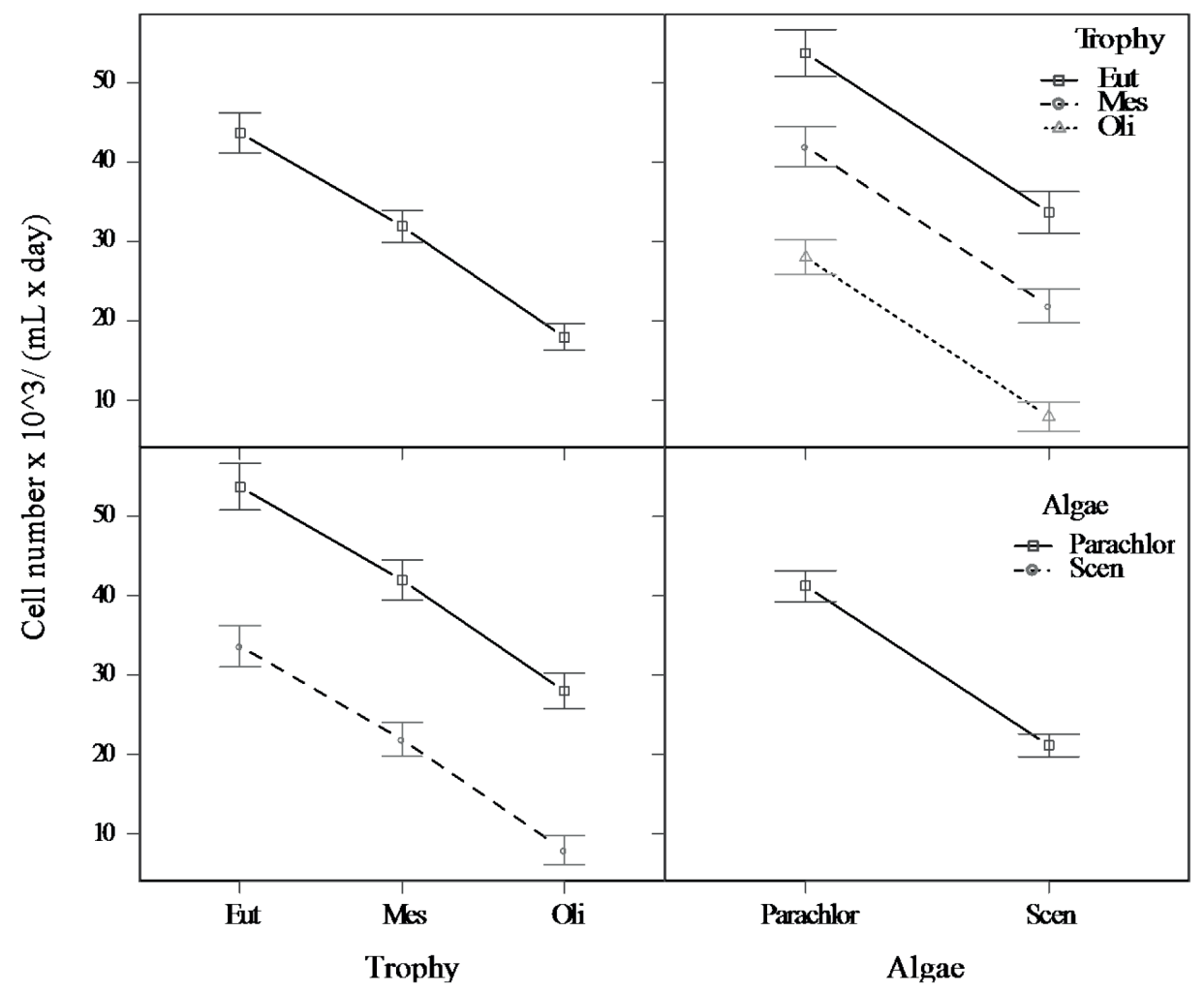

Figure 3. Interaction plots of growth rate (vertical axis) vs. trophic states and algae species (horizontal axis), for the laboratory tests. Growth rates are expressed as the slope coefficient of the number of cells. Eut: laboratory eutrophic test; Mes: laboratory mesotrophic test; Oli: laboratory oligotrophic test; Trophy: trophic test; Algae: algae species; Parachlor: P. kessleri; Scen: S. obtusus. Standard deviations of growth rate estimates are shown. Gráficos de interacción de la tasa de crecimiento (eje vertical) vs. los estados tróficos y las especies de algas (eje horizontal), para las pruebas de laboratorio. Las tasas de crecimiento se expresan como el coeficiente de la pendiente del número de células. Eut: prueba eutrófica de laboratorio; Mes: prueba mesotrófica de laboratorio; Oli: prueba oligotrófica de laboratorio; Trophy: prueba trófica; Algae: especies de algas; Paraclor: P. kessleri; Scen: S. obtusus. Se muestran las desviaciones estándar de las estimaciones de la tasa de crecimiento. 
The model selection followed Gałecki \& Burzykowski (2013). The variance structure was determined using the F-test and Akaike information criterion (AIC). Once the variance structure was defined, the mean structure was assessed as follows: a first model with complete interactions between covariates was fitted; then, when possible, simplified models were selected based on the significance of the interaction terms established by ANOVA Type II tests, F-test and AIC. It should be noted that the most important parameters of these models were associated with time, which include parameters associated with growth rate differences between algae species and trophic states, or wetland and climatic season, respectively. After obtaining the selected model, contrasts were obtained to test for differences among the growth rates under the different studied conditions (De Rosario-Martinez, 2013).

For the analysis of abiotic variables under field conditions, we aimed to assess differences between wetlands and climatic seasons for the physicochemical variables. La Conejera wetland was excluded because it was only sampled in the rainy season. For this analysis, multivariate general linear models (MGLM) were used. In this case, the response is not a single variable but a vector of physicochemical variables. This analysis was done separately for the physical (temperature, conductivity, solids, PAR radiation) and chemical (nutrients, oxygen demands) variables. The strategy for model selection and contrast analysis was the same as for the analysis of the mean structure in the LMHV. All analyses were carried out using the R software (R Development Core Team, 2018).

\section{RESULTS}

\section{Laboratory tests}

The growth curves were consistent with the amount of nutrients provided by each simulated media (Fig. 2). Growth was higher for the eutrophic medium than for the oligotrophic and mesotrophic simulated trophic states, especially for P. kessleri (Fig. 2B). In both species, growth during the first days of culture was quite similar, independent of nutrient concentration. The growth curves of $S$. obtusus in the oligotrophic and mesotrophic media exhibited similar behavior and were clearly lower than in the eutrophic state (Fig. 2A). This species displayed a tendency for faster adaptation and earlier growth during the initial days of the culture; then, on the fifth day, the growth in the eutrophic medium began to be different from that of the other treatments although, on the sixth and eighth days, the difference was low. P. kessleri showed greater growth under the eutrophic conditions (Fig. 2B), but, unlike $S$. obtusus, its growth curves in the mesotrophic and oligotrophic media were different, with higher growth in the mesotrophic state. The response of $P$. kessleri to the eutrophic state was notably more evident than that of S. obtusus, even though both species exhausted the nutrients in the eutrophic medium at about the same time (day 9-10). In the oligotrophic medium, $S$. obtusus seemed to have exhausted the nutrients first (had the fastest initial growth rate); its exponential phase of growth ended on day 3 as opposed to day 4 for $P$. kessleri. As a possible hypothesis, we suggest that later peaks of $P$. kessleri on day 12 (Fig. 2B) could represent growth promoted by nutrients regenerated from dead cells within the beads.

The LMHV results for these experiments indicated that the nutritional medium and alga species had independent effects on the growth rates since the triple interaction term involving time, alga and trophic state was not significant $(p=0.30)$. The post-hoc analysis indicated that

Table 1. Estimates of the growth rate contrasts between trophic states and algae species for the laboratory tests. Estimaciones de los contrastes de la tasa de crecimiento entre estados tróficos y especies de algas para las pruebas de laboratorio.

\begin{tabular}{ccc}
\hline Contrast & Value & $\operatorname{Pr}(>\mathbf{F})$ \\
\hline Eutrophic-Mesotrophic & 11784 & 0.00043 \\
Eutrophic-Oligotrophic & 25757 & $<2.2 .10^{-16}$ \\
Mesotrophic-Oligotrophic & 13973 & $2.2 .10^{-7}$ \\
P. kessleri-S. obtusus & 20108 & $<2.2 .10^{-16}$ \\
\hline
\end{tabular}


Table 2. Means, maximum, and minimum values of the physical and chemical factors measured in the studied wetlands for the two climatic periods. Promedios, valores máximos y valores mínimos de los factores físicos y químicos medidos en los humedales estudiados para los dos períodos climáticos.

\begin{tabular}{|c|c|c|c|c|c|c|c|c|c|c|c|c|c|c|c|c|c|c|c|c|c|}
\hline \multirow{3}{*}{ Variable } & \multicolumn{6}{|c|}{ San Rafael } & \multicolumn{6}{|c|}{ Santa María } & \multirow{2}{*}{\multicolumn{3}{|c|}{$\frac{\text { La Conejera }}{\text { Rainy }}$}} & \multicolumn{6}{|c|}{ Juan Amarillo } \\
\hline & \multicolumn{3}{|c|}{ Dry } & \multicolumn{3}{|c|}{ Rainy } & \multicolumn{3}{|c|}{ Dry } & \multicolumn{3}{|c|}{ Rainy } & & & & \multicolumn{3}{|c|}{ Dry } & \multicolumn{3}{|c|}{ Rainy } \\
\hline & Mean & Max & Min & Mean & Max & Min & Mean & Max & Min & Mean & Max & Min & Mean & Max & Min & Mean & Max & Min & Mean & Max & Min \\
\hline Temperature $\left({ }^{\circ} \mathrm{C}\right)$ & 17.1 & 17.7 & 16.7 & 17.9 & 18.9 & 16.8 & 17.7 & 20 & 17 & 18.1 & 19.9 & 17.4 & 16 & 17.4 & 13.8 & 20.9 & 24.7 & 15.5 & 18 & 20.8 & 15.6 \\
\hline Conductivity $(\mu \mathrm{S} / \mathrm{cm})$ & 59.3 & 60.1 & 58 & 54.9 & 59.9 & 52.1 & 195.1 & 199 & 192 & 165.5 & 175.9 & 160.8 & 264.4 & 307 & 232 & 879.8 & 1102 & 539 & 654.7 & 921 & 336 \\
\hline Dissolved solids (mg/L) & 29.6 & 30.1 & 29 & 29.5 & 31.8 & 28.5 & 97.5 & 99.5 & 96 & 91.1 & 95.4 & 90 & 154.5 & 180.4 & 139.1 & 465.3 & 550 & 287 & 370.4 & 531 & 194.3 \\
\hline pH (units) & 7.9 & 8.08 & 7.15 & 7.4 & 7.6 & 7.3 & 7.5 & 7.8 & 7.3 & 7.4 & 7.64 & 6.96 & 7.1 & 7.18 & 7.0 & 7.2 & 7.3 & 7.15 & 7.3 & 7,46 & 6.99 \\
\hline Dissolved oxygen (mg/L) & 6.8 & 7.08 & 6.6 & 6.9 & 7.3 & 6.7 & 4.5 & 6.3 & 3.7 & 3.8 & 5.25 & 2.17 & 2.1 & 3.1 & 1.14 & 0.4 & 0.57 & 0.17 & 0.4 & 1.29 & 0 \\
\hline $\begin{array}{l}\text { Oxygen saturation } \\
\left(\mathrm{O}_{2} \%\right)\end{array}$ & 99 & 102.3 & 96.7 & 104 & 108.3 & 97.2 & 64.1 & 95.6 & 52.2 & 53.3 & 75.8 & 17.4 & 28.5 & 43 & 14.8 & 5.5 & 8.6 & 2.4 & 6.4 & 19 & 0 \\
\hline PAR $\left(\mu \mathrm{mol} \mathrm{m} \mathrm{m}^{-2} \mathrm{~s}^{-1}\right)$ & 545.9 & 1997 & 94.3 & 1051 & 2732 & 347 & 645.8 & 2460 & 173.3 & 553.2 & 2589 & 145.7 & 270 & 542 & 100.1 & 420 & 1983 & 101.6 & 243 & 1449 & 39.7 \\
\hline Light transmittance (\%) & 80.4 & 96.1 & 58.6 & 85.5 & 95.5 & 71.6 & 80.3 & 88 & 71.3 & 76.2 & 91.5 & 55.8 & 86 & 94.9 & 75.6 & 48.1 & 63.5 & 36.7 & 35.4 & 54.1 & 15 \\
\hline Redox potential $(\mathrm{mV})$ & 225 & 246.9 & 195.3 & 76.8 & 106.4 & 40.5 & 174.9 & 298.4 & 105.4 & 158.2 & 198.7 & 105.7 & 55.3 & 104.2 & 11.7 & -284.4 & -307.7 & -247.1 & -205.8 & -248.5 & -92 \\
\hline $\mathbf{N H}_{4}^{+}(\mathrm{mg} / \mathrm{L})$ & 0.9 & 1.1 & 0.7 & 0.6 & 0.66 & 0.53 & 0.3 & 0.6 & 0.1 & 0.08 & 0.1 & 0.06 & 0.12 & 0.13 & 0.1 & 64.3 & 73.3 & 55.1 & 26.5 & 45.9 & 12.3 \\
\hline $\begin{array}{l}\text { Chemical oxygen } \\
\text { demand }(\mathrm{mg} / \mathrm{L})\end{array}$ & 6.5 & 7 & 6 & 12 & 20 & 8 & 13 & 18 & 9 & 11.7 & 16 & 6 & 20.7 & 24 & 19 & 227 & 302 & 145 & 270.7 & 372 & 164 \\
\hline $\begin{array}{l}\text { Total phosphorus } \\
(\mathrm{mg} / \mathrm{L})\end{array}$ & 0.1 & 0.11 & 0.09 & $<0.10$ & $<0.10$ & $<0.10$ & 0.13 & 0.18 & 0.1 & $<0.10$ & $<0.10$ & $<0.10$ & 0.33 & 0.38 & 0.28 & 17.6 & 22.2 & 14.5 & 7.4 & 7.9 & 4.5 \\
\hline Total nitrogen $(\mathrm{mg} / \mathrm{L})$ & 1.17 & 1.4 & 0.94 & 0.78 & 0.85 & 0.68 & 0.63 & 0.82 & 0.54 & $<0.54$ & $<0.54$ & $<0.54$ & $<0.54$ & $<0.54$ & $<0.54$ & 82.7 & 94.1 & 70.5 & 33.9 & 58.8 & 15.9 \\
\hline
\end{tabular}

each trophic state had a different growth rate, and, indeed, a clear trend was observed (Fig. 3 and Table 1). The variance structure selected for this model was given by $\operatorname{var}\left(N_{t i}\right)=\left|\mu_{t i}\right| \delta$, where $\mu \mathrm{ti}$ was given by the mean structure of the model (i.e. time, trophic state, and alga species) and $\delta$ was a parameter to be estimated $(0.816357295 \%$ IC [0.7085846-0.9241299]).

\section{Field trials}

In general, the physical and chemical variables showed low seasonal variation in all wetlands (Table 2). In contrast, between some wetlands, the variables relating to nutrient concentration and organic matter (ammonium, total phosphorous, total nitrogen, chemical oxygen demand, oxygen saturation, conductivity, dissolved solids) differed. Juan Amarillo presented extreme values with concentrations of $\mathrm{NH}_{4}^{+}$that may have been toxic to the encapsulated algae and conductivity that may have been too high. The temperature and $\mathrm{pH}$ showed little variation between the wetlands, while PAR exhibited great dissimilarities. The low PAR value in La Conejera was due to the tree cover, while in Juan Amarillo it was due to the low water light transmittance (TrL).
Table 3. Multivariate linear model contrasts for physical and chemical variables in the wetlands: San Rafael (SR, oligotrophic state), Santa María (SM, mesotrophic state), and Juan Amarillo (JA, hypertrophic state), in dry and rainy periods. Contrastes de los modelos lineales multivariados de para las variables fisicas y químicas en los humedales: San Rafael (SR, estado oligotrófico), Santa María (SM, estado mesotrófico) y Juan Amarillo (JA, estado hipertrófico), en períodos secos y lluviosos.

\begin{tabular}{cccc}
\hline Term & Df & $\boldsymbol{p}$-value & $\begin{array}{c}\text { Significance } \\
\text { level }\end{array}$ \\
\hline Time & 1 & $4.11 \cdot 10^{-6}$ & 0.001 \\
Wetland & 2 & $<2.2 \cdot 10^{-16}$ & 0.001 \\
Alga & 1 & $<2.2 \cdot 10^{-16}$ & 0.001 \\
Temperature & 1 & $1.50 \cdot 10^{-7}$ & 0.001 \\
Time:Wetland & 2 & $<2.2 \cdot 10^{-16}$ & 0.001 \\
Time:Alga & 1 & $2.9 \cdot 10^{-1}$ & \\
Wetland:Alga & 2 & $<2.2 \cdot 10^{-16}$ & 0.001 \\
Wetland:Temp & 2 & $1.0 \cdot 10^{-2}$ & 0.05 \\
Alga:Temp & 1 & $1.54 \cdot 10^{-6}$ & 0.001 \\
Time:Wetland:Alga & 2 & $1.79 \cdot 10^{-13}$ & 0.001 \\
Wetland:Alga:Temp & 2 & $1.30 \cdot 10^{-6}$ & 0.001 \\
\hline
\end{tabular}


From a statistical point of view, the MGLM analysis showed that Juan Amarillo was the only wetland where significant differences were found in the chemical variables between seasons $(p=0.0002)$, while the physical variables showed consistent differences between the seasons at all sites. A contrast between the wetlands revealed that Santa María and San Rafael were not significantly different in terms of chemical characteristics, whereas the remaining comparisons yielded significant differences (Table 3 ).

In San Rafael, there were differences in the growth of the species in the dry season (Fig. 4A). S. obtusus exceeded the growth curve of $P$. kessleri in this oligotrophic wetland, whereas the $P$. kessleri growth was higher in Santa María (mesotrophic) (Fig. 4B). The higher species growths were recorded in La Conejera (eutrophic), where initially the two species grew similarly until the seventh day, after which $P$. kessleri grew faster than S. obtusus (Fig. 4C). In Juan Amarillo (hypereutrophic), both species exhibited negative growth because of cell death (Fig. 4D). In all cases, the control beads showed that neither light nor temperature is a limiting factor for algal growth.

The LMHV results for the field trials indicated a lack of differences in growth rates between seasons since interactions involving time and season were not significant (likelihood ratio test comparing the saturated model [full interactions] $v s$. the final selected model [without interactions
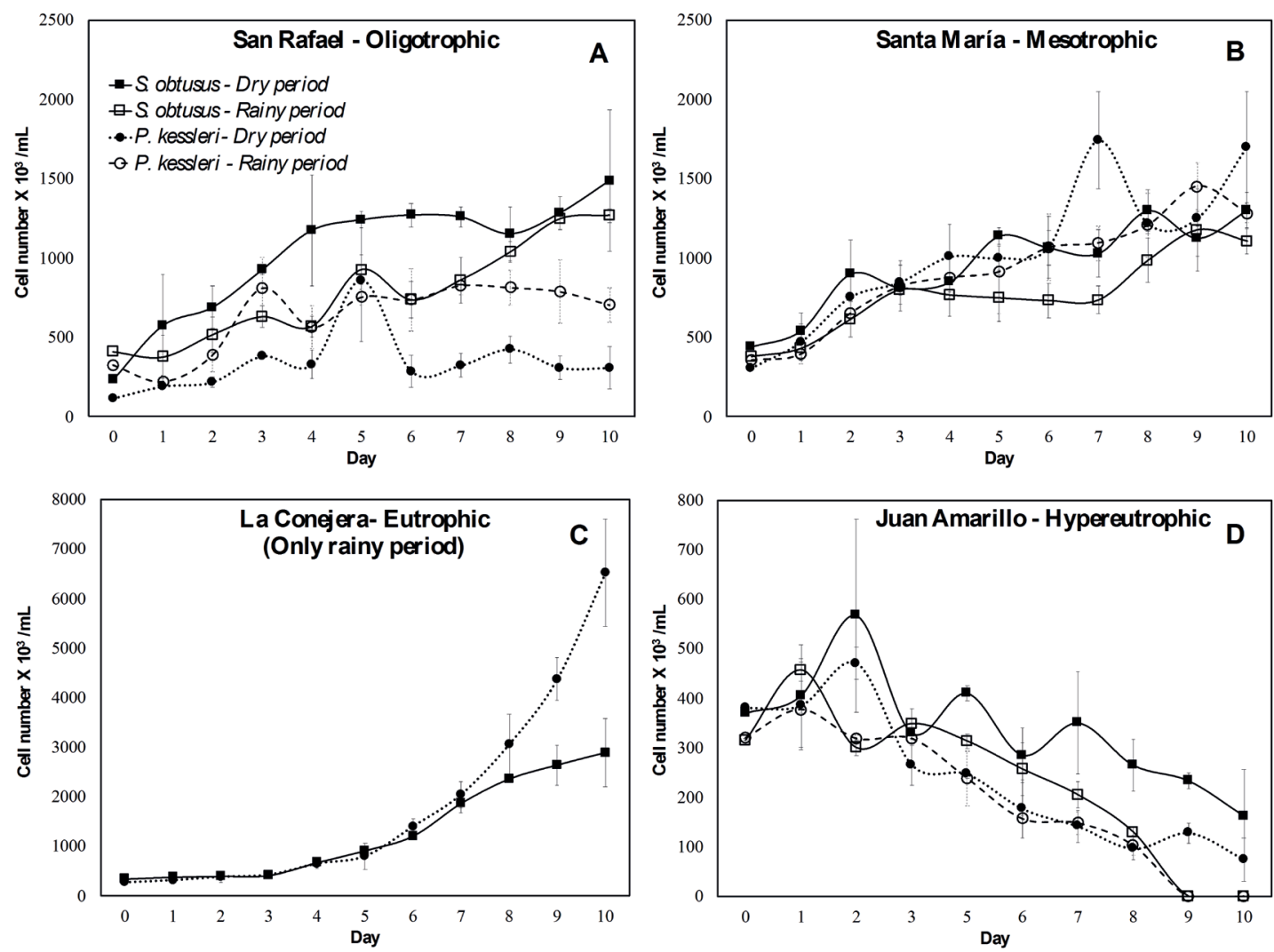

Figure 4. Growth curves of algae exposed to wetlands of different trophic state. A. San Rafael of oligotrophic state. B. Santa María of mesotrophic state. C. La Conejera of eutrophic state. D. Juan Amarillo of hypereutrophic state. Standard deviations of cell numbers are shown. Curvas de crecimiento de algas expuestas a humedales de diferente estado trófico. A. San Rafael de estado oligotrófico. B. Santa María de estado mesotrófico. C. La Conejera de estado eutrófico. D. Juan Amarillo de estado hipereutrófico. Se muestran las desviaciones estándar del número de células. 


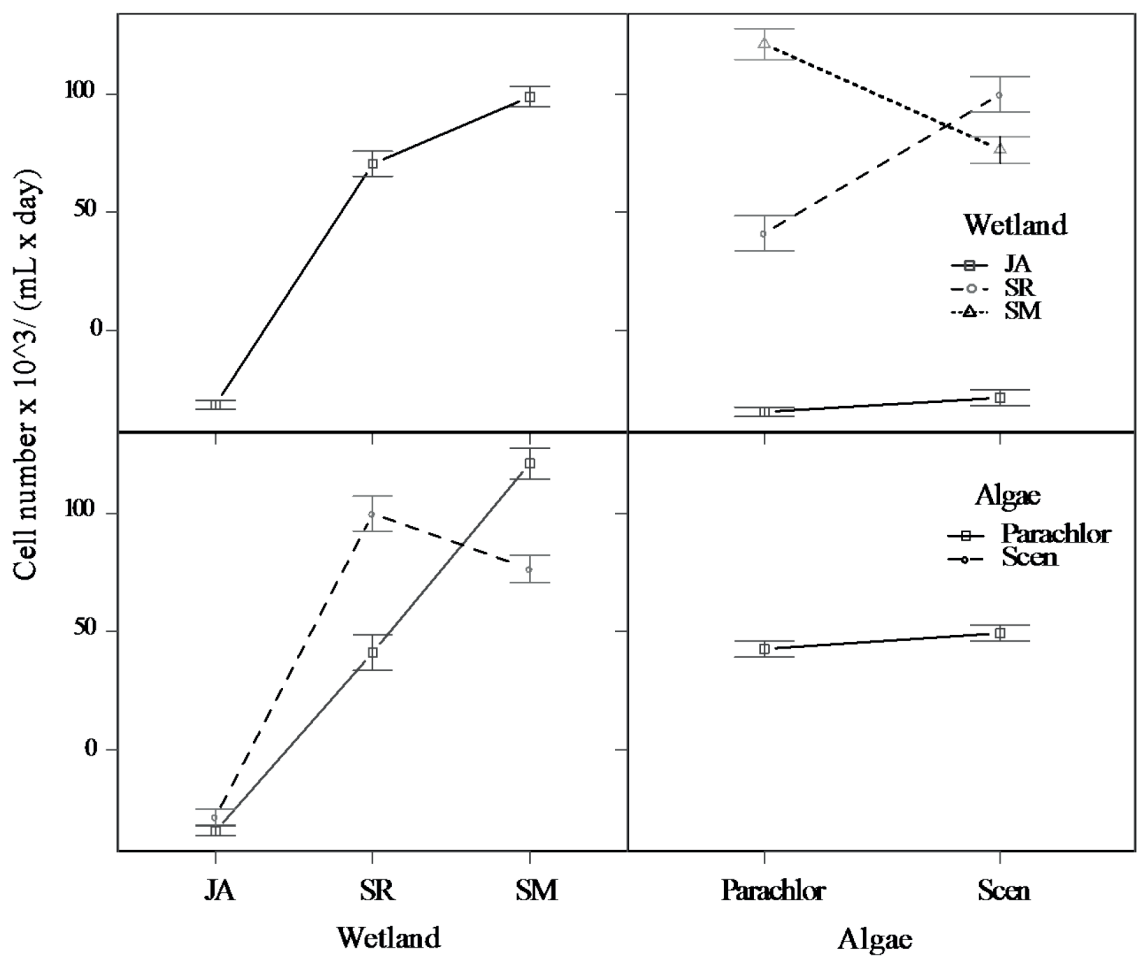

Figure 5. Interaction plots of algae growth rate (vertical axis) vs. wetlands and algae species (horizontal axis) for the field trials. Growth rates are expressed as the slope coefficient of the number of cells. JA: Juan Amarillo; SM: Santa María; SR: San Rafael; Parachlor: P. kessleri; Scen: S. obtusus. Standard deviations of growth rate estimates are shown. Gráficos de interacción de la tasa de crecimiento de las algas (eje vertical) vs. los humedales y las especies de algas (eje horizontal) para los ensayos de campo. Las tasas de crecimiento se expresan como el coeficiente de la pendiente del número de células. JA: Juan Amarillo; SM: Santa María; SR: San Rafael; Paraclor: P. kessleri; Scen: S. obtusus. Se muestran las desviaciones estándar de las estimaciones de la tasa de crecimiento.

between season and other factors with time], $p=0.154)$. However, interactions between time (the day of the experiment), algae, and wetlands were significant, implying a complex behavior of growth rate depending on a combination of species and place (Table 4). A clearer picture of this can be observed in figure 5, in which $P$. kessleri has a well-defined trend for increased growth rates, whereas the trend is different for $S$. obtusus. All comparisons between the wetlands and algae were significant, except for Juan Amarillo, where there was no significant difference in growth rates between the algae species (Fig. 5 and Table 5). The variance structure for these models was similar to laboratory tests; however, a different $\delta_{P A}$ parameter is needed for each combination of wetland and alga to fully explain the observed data variation.
Table 4. Type II ANOVA showing the significance of terms in the model for the field trials. Terms involving the Time variable are related to growth rate interactions. ANOVA Tipo II que muestra la importancia de los términos en el modelo para los ensayos de campo. Los términos que involucran la variable Tiempo están relacionados con las interacciones de la tasa de crecimiento.

\begin{tabular}{cccc}
\hline Contrast & Fixed & Physic $\boldsymbol{p}$-val & Chemical $\boldsymbol{p}$-val \\
\hline Rainy-Dry & JA & $1.6 \cdot 10^{-2}$ & $2.1 \cdot 10^{-4}$ \\
Rainy-Dry & SM & $3.4 \cdot 10^{-4}$ & $2.3 \cdot 10^{-1}$ \\
Rainy-Dry & SR & $7.3 \cdot 10^{-12}$ & $0.5 \cdot 10^{-1}$ \\
JA-SM & Rainy & $<2.2 \cdot 10^{-16}$ & $1.1 \cdot 10^{-3}$ \\
JA-SR & Rainy & $<2.2 \cdot 10^{-16}$ & $1.1 \cdot 10^{-3}$ \\
SM-SR & Rainy & $1.2 \cdot 10^{-11}$ & $2.9 \cdot 10^{-1}$ \\
JA-SM & Dry & $<2.2 \cdot 10^{-16}$ & $6.7 \cdot 10^{-4}$ \\
JA-SR & Dry & $<2.2 \cdot 10^{-16}$ & $6.2 \cdot 10^{-4}$ \\
SM-SR & Dry & $1.5 \cdot 10^{-8}$ & $4.9 \cdot 10^{-1}$ \\
\hline
\end{tabular}




\section{DISCUSSION}

Biological communities are structured through the selection that the environmental filter exerts on species. In our case, the results show that immobilized phytoplankton species respond differently to nutrients concentration, given that one species is more sensitive to changes in the amount of nutrients than the other species. The response of population attributes (e.g., density, growth rate) to variations in the trophic conditions of aquatic environments (wetlands) depended on the inherent characteristics of the species and the amount of nutrients available to it.

\section{Encapsulated algae under laboratory condi- tions}

The species $S$. obtusus is a very abundant alga and frequently reported in nutrient-rich waters, mainly enriched with nitrogen (Wehr \& Sheath, 2003). The similarity in the growth curves of this species in oligotrophic and mesotrophic media (Fig. 2A) may be due to the already mentioned range of tolerance, which allows better growth at high levels of nutrients. Thus, it seems that $S$. obtusus has a low degree of sensitivity between conditions with a lower concentration of nutrients. More detailed studies will be required to establish the exact boundaries of these elements from which this taxon begins to show detectable changes in growth. In contrast, P. kessleri, a species recently separated from the Chlorella genus (Krienitz et al., 2004), has a wide range of tolerance for nutrient concentrations, allowing it to be in any trophic state. However, this taxon is commonly reported as frequent and abundant in waters with medium to low concentrations of nutrients (Wehr \& Sheath, 2003). Perhaps, this is why it has greater growth in mesotrophic media than in oligotrophic media (Fig. 2B). Nevertheless, P. kessleri grows well under eutrophic conditions, matching the development of S. obtusus in the same circumstances. These results showed clear contrasts in the response of $P$. kessleri to the different trophic states, compared to the other species, at least under the laboratory conditions. Higher growth has been recorded for P. kessleri (Chlorella) than Scenedesmus (Forero-Cujiño et al., 2016), agreeing with the present research, but that study used free algae (not encapsulated), cultured with optimal concentrations of nutrients. In this regard, a previous study by us estimated the effects of encapsulation in algae, as compared to free algae (Delgadillo et al., 2017), where the cell density and concentration of chlorophyll decreased in the encapsulated algae because of limited space. However, photosynthetic efficiency, measured as variable fluorescence over maximum fluorescence $(\mathrm{Fv} / \mathrm{Fm})$, and growth rates remained the same under both conditions.

The laboratory LMHV results confirmed the observations made for the growth curves of the alginate-encapsulated microalgae. The recreated

Table 5. Estimates of the growth rate contrasts between wetlands and algae species for the field trials. JA: Juan Amarillo; SM: Santa María; SR: San Rafael. Estimaciones de los contrastes de la tasa de crecimiento entre humedales y especies de algas para los ensayos de campo. JA: Juan Amarillo; SM: Santa Maria; SR: San Rafael.

\begin{tabular}{clccc}
\hline Contrast & Fixed & Value & p-value & \multicolumn{2}{c}{$\begin{array}{c}\text { Significance } \\
\text { level }\end{array}$} \\
\hline JA-SR & P. kessleri & -73589 & $<2.2 .10^{-16}$ & 0.001 \\
JA-SM & P. kessleri & -154040 & $<2.2 .10^{-16}$ & 0.001 \\
SR-SM & P. kessleri & -80451 & $<2.2 .10^{-16}$ & 0.01 \\
JA-SR & S. obtusus & -126937 & $<2.2 .10^{-16}$ & 0.001 \\
JA-SM & S. obtusus & -103337 & $<2.2 .10^{16}$ & 0.001 \\
SR-SM & S. obtusus & 23600 & $3.8 .10^{-2}$ & 0.05 \\
P. kessleri - S. obtusus & JA & -7111 & $7.1 .10^{-2}$ & 0.1 \\
P. kessleri - S. obtusus & SR & -60459 & $4.9 .10^{-7}$ & 0.001 \\
P. kessleri - S. obtusus & SM & 43593 & $1.2 .10^{-6}$ & 0.001 \\
\hline
\end{tabular}


trophic conditions produced changes in the growth rates of the two species, with P. kessleri as the alga that grew faster. The experiments showed growth differences between the two immobilized algae species because the effects of the nutrients were clearly separated and did not cross. Based on the LMHV analysis, P. kessleri always develops more vigorously, independent of the trophic status. Overall, the effect of the nutrient concentration on the growth of the encapsulated algae was the same regardless of the species, that is, the number of algae was always higher in the eutrophic medium than in the oligotrophic and mesotrophic waters.

\section{Encapsulated algae exposed to field conditions}

It appears that the growth curves of $P$. kessleri and $S$. obtusus were related to nutrient availability. This variable was low in waterbodies with fewer nutrients and higher in the eutrophic wetland. Acute organic load and excessive nutrient conditions, as occur in the Juan Amarillo wetland (hypereutrophic), proved to be adverse for both species of encapsulated algae. In the La Conejera wetland (eutrophic), the algae showed higher growth rates, indicating that the nutritional conditions there were the best. This response appears to have been favored by high but not excessive nutrient availability, probably because of moderate light intensity, since the experiment area in this wetland was partially shaded by riparian trees.

According to the statistical analyses, in the field trials, the growth behavior of the encapsulated algae was not independent but was determined first by the alga species and secondly by the wetland conditions. In other words, the differences in algal growth between the wetlands depended mainly on the species. The LMHV analysis suggests that $P$. kessleri reached the highest growth in the Santa María wetland. Given that the MGLM test (Table 3) indicated that there were differences in the physical variables between the wetlands, it is feasible that such physical conditions (temperature, conductivity, dissolved solids, PAR) were more favorable for this alga in Santa María than in the other wetlands. In the oligotrophic water of San Rafael wetland, higher growth of S. obtusus was observed, as confirmed by the LMHV analysis, possibly favored by better physical conditions (greater transparency and therefore more light penetration). Figure 4A also indicates that the cell growth had differences between species in the San Rafael wetland. As seen in other studies, there are some conditions besides the amount of nutrients (such as the initial inoculum concentration, the light intensity, and the alga functional characteristics) that can influence the establishment and development of microalgae (Forehead \& O'kelly, 2013; Gatamaneni Loganathan et al., 2018).

The Juan Amarillo wetland (hypereutrophic) showed extremely harmful conditions, both for the species and the calcium alginate beads. The MGLM proved that the chemical conditions in Juan Amarillo were different between periods and compared to the other wetlands. Although species of the Chlorella clade and Scenedesmus genera, particularly P. kessleri and S. obtusus, have been associated with high pollution and high nutrient concentrations (Bellinger \& Sigee, 2010; O'Rourke et al., 2016), the harsh physicochemical characteristics of Juan Amarillo apparently exceeded the tolerance of these organisms. Low light availability, minimum oxygen concentration, and high values of ammonium, conductivity, and organic matter registered in this wetland (Table 2) were probably the causes of the extremely adverse effects observed on the algae growth (Pearson et al., 1987; Athayde, 2001;), which were negative for the two species. The severe chemical conditions of this wetland also affected the calcium alginate matrix; initially, the volume of the beads increased, causing a loss in the matrix compaction; then, the viscosity increased, and fragmentation occurred in some beads. During the rainy season, when the highest concentration of phosphate was registered, the effect on the alginate was so intense that, by the ninth day of the experiment, the beads were fully dissolved. Phosphate ions remove $\mathrm{Ca}^{2+}$ cations (responsible for maintaining the structure of calcium alginate), leading to an initial increase in viscosity, a subsequent decrease in the elastic force of the gel, and further dilution (Barsanti \& Gualtieri, 2006; Donati \& Paoletti, 2009). The loss of the mechanical strength of the alginate probably favored cell loss and influenced the 
population decline of the immobilized microalgae (Dainty et al., 1986; Moreira et al., 2006).

\section{CONCLUSIONS}

Our results are the first approximation of the response of encapsulated algae to different levels of nutrients. The results suggest that responses of algae growth under field conditions could change depending on the algal concentration and the complex influence of environmental variables. Therefore, more research is needed, but, for the moment, if the growth rate is high, especially in $P$. kessleri, the aquatic ecosystem is very likely eutrophic. The population dynamics of algae species embedded in alginate beads may be used as a possible technique to evaluate the trophic conditions of aquatic environments, although detailed experiments are required on the physiological response of algae to a given nutrient concentration. In this way, the encapsulation of microalgae in alginate could foster a better understanding of the key factors in the development and establishment of these species under natural conditions. Research with encapsulated algae avoids the limitations of studies carried out with free algae because encapsulated organisms can be recovered from the environment, but there are also restrictions since the availability of space for algae growth is restricted within the beads.

\section{ACKNOWLEDGMENTS}

We thank the research groups "Biodiversity, biotechnology and conservation of ecosystems" and "Stress physiology and biodiversity in plants and microorganisms", and the Laboratories of Ecology, Algal Culture, and Plant Physiology and Biochemistry of the Biology Department of the Universidad Nacional de Colombia. This work was supported by the Colombian Departamento Administrativo de Ciencia, Tecnología e Innovación (COLCIENCIAS), and the Universidad Nacional de Colombia (grant 462-2011).

\section{REFERENCES}

ANDERSEN, A. R. 2005. Algal culturing techniques. Academic Press, Burlington, Mass. USA.
ATHAYDE, S. T. 2001. Algal and bacterial dynamics in waste stabilization ponds and wastewater storage and treatment reservoirs. Ph.D. Thesis. University of Liverpool, UK.

BARSANTI, L. \& P. GUALTIERI. 2006. Algae: anatomy, biochemistry, and biotechnology. CRC Press, Roca Raton. USA. DOI: 10.1111/ j.1529-8817.2007.00335.x

BELLINGER, E. G. \& D. C. SIGEE. 2010. Freshwater algae: identification and use as bioindicators. Wiley-Blackwell, Chichester. UK. DOI: 10.1002/9780470689554

BOURAÏ, L., M. LOGEZ, C. LAPLACE-TREYTURE \& C. ARGILLIER. 2020. How do eutrophication and temperature interact to shape the community structures of phytoplankton and fish in lakes? Water, 12(779). DOI: $10.3390 /$ w12030779

CORRÊA, A. X., M. S. TAMANAHA, C. O HORITA, M. R. RADETSKI, R. CORREAA \& C. M. RADETSKI. 2009. Natural impacted freshwaters: in situ use of alginate immobilized algae to the assessment of algal response. Ecotoxicology, 18: 464-469. DOI: 10.1007/s10646-009-0301-x

DAINTY, A. L., K. H. GOULDING, P. K. ROBINSON, I. SIMPKINS \& M. D. TREVAN. 1986. Stability of alginate-immobilized algal cells. Biotechnology and Bioengineering, 28: 210-216. DOI: 10.1002/bit.260280210

DE ROSARIO-MARTINEZ, H. 2013. Package 'phia': Post-Hoc Interaction Analysis. R package version 0.1-5 [Internet]. Available at: http://CRAN.R-project.org/package $=$ phia [Accessed: 2018-02-05]

DE-BASHAN, L., P. MAGALLON, H. ANTOUN \& Y. BASHAN. 2008. Role of glutamate dehydrogenase and glutamine synthetase in Chlorella vulgaris during assimilation of ammonium when jointly immobilized with the microalgae-growth-promoting bacterium Azospirillum brasilense. Journal of Phycology, 44(5): 1188-1196. DOI: 10.1111/ j.1529-8817.2008.00572.x

DELGADILLO, I. P., L. C. MONTENEGRO, G. A. PINILLA \& L. M. MELGAREJO. 2017. Medición de la fluorescencia de la clorofila a en algas encapsuladas en alginato de calcio. Acta Biológica Colombiana, 22(2): 199-208. 
DOI: 10.15446/abc.v22n2.56166. DOI: 10 . 15446/abc.v21n2.51253

DONATI, I. \& S. PAOLETTI. 2009. Material properties of alginates. In: Alginates: biology and applications. B. H. Rehm (ed.): 2-53. Springer-Verlag, Berlin. Germany. DOI: 10. 1007/978-3-540-92679-5

EROGLU, E., S. M. SMITH \& C. L. RASTON. 2015. Application of various immobilization techniques for algal bioprocesses. In: Biomass and biofuel from microalgae. Advances in Engineering and Biology. N. R. Moheimani, M. P. McHenry, K. de Boer \& P. Bahri (eds): 19-44. Springer, New York. USA. DOI: 10. 1007/978-3-319-16640-7_2

FOREHEAD, H. I. \& C. J. O'KELLY. 2013. Small doses, big troubles: modeling growth dynamics of organisms affecting microalgal production cultures in closed photobioreactors. Bioresource Technology, 129: 329-334. DOI: $10.1016 /$ j.biortech.2012.11.082

FORERO-CUJIÑO, M., L. C. MONTENEGRO-RUÍZ，G. PINILLA-AGUDELO \& L.M. MELGAREJO. 2016. Inmovilización de las microalgas Scenedesmus ovalternus (Scenedesmaceae) y Chlorella vulgaris (Chlorellaceae) en esferas de alginato de calcio. Acta Biológica Colombiana, 21(2): 437-442. DOI: 10.15446/abc.v22n2.56166

GAŁECKI, A. \& T. BURZYKOWSKI. 2013. Linear mixed-effects models using $R: a$ step-by-step approach. Springer Science+ Business Media, New York. USA. DOI: 10.1007/978-1-4614-3900-4

GATAMANENI LOGANATHAN, B., V. ORSAT \& M. LEFSRUD. 2018. Factors affecting growth of various microalgal species. Environmental Engineering Science, 35(10): 1037-1048. DOI: 10.1089/ees.2017. 0521

GUILLOT, G. \& G. PINILLA (eds). 2017. Estudios ecológicos en humedales de Bogotá. Aplicaciones para su evaluación, seguimiento y manejo. Editorial Universidad Nacional de Colombia, Bogotá. Colombia.

GUNKEL, G., D. LIMA, F. SELGE, M. SOBRAL \& S. CALADO. 2015. Aquatic ecosystem services of reservoirs in semi-arid areas: sustainability and reservoir manage- ment. WIT Transactions on Ecology and the Environment, 197: 187-200. DOI: 10.2495/ RM150171

KIRK, J. 2011. Light and photosynthesis in aquatic ecosystems (3rd ed). Cambridge University Press, Cambridge. UK. DOI: 10.1017/ CBO9781139168212

KRIENITZ, L., E. H. HEGEWALD, D. HEPPERLE, V. A. R. HUSS, T. ROHR \& M. WOLF. 2004. Phylogenetic relationship of Chlorella and Parachlorella gen. nov. (Chlorophyta, Trebouxiophyceae). Phycologia, 43: 529-542. DOI: 10.2216/i0031-8884-43-5-529.1

LI, X., PŘIBYL, P., K. BIŠOVÁ, S. KAWANO, V. CEPÁK, V. ZACHLEDER, M. ČÍŽKOVÁ, I. BRÁNYIKOVÁ \& M. VÍTOVÁ. 2013. The microalga Parachlorella kessleri. A novel highly efficient lipid producer. Biotechnology and Bioengineering, 110(1): 97-107. DOI: 10.1002/bit.24595

LUAN, T., J. JIN, S. CHAN, Y. WONG \& N. TAM. 2006. Biosorption and biodegradation of tributyltin (TBT) by alginate immobilized Chlorella vulgaris beads in several treatment cycles. Process Biochemistry, 41: 1560-1565. DOI: $10.1016 /$ j.procbio.2006.02.020

MEYEN, F. J. F. 1829. Beobachtungen über einige niedere Algenformen. Nova Acta Physico-medica, 14: 768-778.

MOREIRA, S. M., M. MOREIRA-SANTOS, L. GUILHERMINO \& R. RIBEIRO. 2006. Immobilization of the marine microalga Phaeodactylum tricornutum in alginate for in situ experiments: bead stability and suitability. Enzyme and Microbial Technology, 38: 135-141. DOI: 10.1016/j.enzmictec.2005.05.005

O'ROURKE, R., M. GAFFNEY \& R. MURPHY. 2016. The effects of Parachlorella kessleri cultivation on brewery wastewater. Water Science and Technology, 73(6): 1401-1408. DOI: $10.2166 /$ wst.2015.618

PEARSON, H. W., D. D. MARA, S. W. MILLS \& D. J. SMALLMAN. 1987. Factors determining algal populations in waste stabilization ponds and the influence of algae on pond performance. Water Science and Technology, 19(12): 131-140. DOI: 10.2166/wst.1987.0137

PINEDA, A., G. PINILLA-AGUDELO, L. C. MONTENEGRO-RUIZ \& L. M. MELGAR- 
EJO. 2017. Does the nutrient concentration of water ecosystems affect growth rates and maximum PSII quantum yield in calcium alginate-encapsulated Scenedesmus ovalternus and Chlorella vulgaris? Limnetica, 36(2): 405-425. DOI: 10.23818/limn.36.12

R DEVELOPMENT CORE TEAM. 2018. R: a language and environment for statistical computing. Viena: R Foundation for Statistical Computing [Internet]. Available from: https:// www.r-project.org [Accessed: 2018-02-05]

REYNOLDS, C. S. 2006. The ecology of phytoplankton. Cambridge University Press, Cambridge. UK. DOI: 10.1017/ CBO9780511542145

REYNOLDS, C. S., V. HUSZAR, C. KRUK, L. NASELLI-FLORES \& S. MELO. 2002. Towards a functional classification of the freshwater phytoplankton. Journal of Plankton Research, 24(5): 417-428. DOI: 10.1093/ plankt/24.5. 417

RICE, E. W., R. B. BAIRD, A. D. EATON \& L. S. CLESCERI (eds). 2012. Standard methods for the examination of water and wastewater. 22nd ed. American Public Health Association Publications, Washington. USA.

RODRÍGUEZ, L. \& G. PINILLA. 2017. El fitoplancton y el grado de trofismo de los humedales Santa María del Lago y Juan Amarillo y del embalse San Rafael. In: Estudios ecológicos en humedales de Bogotá. Aplicaciones para su evaluación, seguimiento $y$ manejo. G. Guillot \& G. Pinilla (eds): 147-168. Editorial Universidad Nacional de Colombia, Bogotá. Colombia.

RUIZ-MARIN, A., L. MENDOZA-ESPINOSA \& T. STEPHENSON. 2010. Growth and nutrient removal in free and immobilized green algae in batch and semi-continuous cultures treating real wastewater. Bioresource Technology, 101: 58-64. DOI: 10.1016/j. biortech.2009.02.076

SUKAČOVÁ, K. \& J. ČERVENÝ. 2017. Can algal biotechnology bring effective solution for closing the phosphorus cycle? Use of algae for nutrient removal. European Journal of
Environmental Sciences, 7(1): 63-72. DOI: 10.14712/23361964.2017.6

TILMAN, D., S. KILHAM \& P. KILHAM. 1982. Phytoplankton community ecology: the role of limiting nutrients. Annual Review of Ecology, Evolution, and Systematics, 13: 349-372. DOI: 10.1146/annurev.es.13.110182.002025

TWIST, H., A. EDWARDS \& G. CODD. 1998. A novel in-situ biomonitor using alginate immobilised algae (Scenedesmus subspicatus) for the assessment of eutrophication in flowing surface waters. Water Resources, 31(8): 2066-2072. DOI: 10.1016/S0043-1354(97) 00035-3

VALDEZ, C., Y. PERENGÜEZ, B. MÁTYÁS \& M. F. GUEVARA. 2018. Analysis of removal of cadmium by action of immobilized Chlorella sp. micro-algae in alginate beads. F1000Research, 7:54. DOI: 10.12688/ f1000research.13527.1

VÉDRINE, C., J. LECLERC, C. DURRIEU \& C. TRAN-MINH. 2003. Optical whole-cell biosensor using Chlorella vulgaris designed for monitoring herbicides. Biosensors and Bioelectronics, 18(4): 457-463. DOI: 10. 1016/S0956-5663(02)00157-4

VOLLENWEIDER, R. A. \& J. J. KEREKES. 1980. Background and summary results of the OECD cooperative program on eutrophication. In: Environmental Protection Agency. Proceedings of International Symposium on Inland Waters and Lake Restoration. EPA 440/5-81-010: 25-36. Environmental Protection Agency, Washington. USA.

WEHR, J. D. \& R. G. SHEATH. 2003. Freshwater algae of North America. Ecology and classification. Academic Press, San Diego. USA.

WETZEL, R. \& G. LIKENS. Limnological analyses, 3rd ed. Springer, New York. USA. DOI: $10.1007 / 978-1-4757-3250-4$

ZHU, W., L. WAN \& L. ZHAO. 2010. Effect of nutrient level on phytoplankton community structure in different water bodies. Journal of Environmental Sciences, 2(1): 32-39. DOI: 10.1016/S1001-0742(09)60071-1. 